\title{
Rural-to-Urban Labor Migration, Household Livelihoods, and the Rural Environment in Chongqing Municipality, Southwest China
}

\author{
Hua Qin
}

Published online: 28 September 2010

(C) Springer Science+Business Media, LLC 2010

\begin{abstract}
Rural migration and its relationship to the rural environment have attracted increasing research interest in recent decades. Rural migration constitutes a key component of human population movement, while rural areas contain most of the world's natural resources such as land and forests. This study empirically evaluates a conceptual framework incorporating rural household livelihoods as an integrative mediating factor between rural migration and the rural environment in the context of rural-to-urban labor migration in Chongqing Municipality, Southwest China. The analysis draws on data collected through household surveys and key informant interviews from four villages. Results confirm the hypothesis that labor-migrant and nonlabor-migrant households differ significantly in livelihood activities including agricultural production, agricultural technology use, income and consumption, and resource use and management. Implications for the subsequent environmental outcomes of rural labor out-migration and corresponding natural resource management and policy in rural origin areas are discussed.
\end{abstract}

Keywords Migration-environment · Mediating factor framework $\cdot$ Migrant households $\cdot$ Non-migrant households $\cdot$ Rural livelihoods $\cdot$ China

H. Qin $(\bowtie)$

Climate Science and Applications Program, National Center for Atmospheric Research,

PO Box 3000, Boulder, CO 80307, USA

e-mail: huaqin@ucar.edu

\section{Introduction}

Since rural migration (to urban or rural areas, permanent or temporary, internal or international) constitutes a key component of human population movement, and rural areas contain most of the world's natural resources, such as land and forests, rural migration and its relationship to the rural environment have attracted increasing interest in recent research on population-environment linkages (Bilsborrow 2002; Carr 2009). In the long-running debate on the relationships between population and the environment, early simplistic views of negative linear relationships between population growth and the natural environment have been replaced by a more complicated mediating factor framework (Jolly 1994; Mackellar et al. 1998; Marquette and Bilsborrow 1999). This approach incorporates socioeconomic, institutional, technological, and cultural contextual factors which modify the relationships between population dynamics and environmental changes. The mediating factor perspective is especially important in investigating the specific mechanisms through which migration affects the environment.

The effects of migration on the environment are often complex, and an accurate examination requires comparing the biophysical situation before and after migration. However, such longitudinal data are not usually available, especially in rural areas of developing countries. Moreover, environmental changes can be attributable to a wide range of factors beyond migration. Therefore, a reasonable and efficient research strategy of differentiating environmental impacts of migration is to compare migrant households (or migrants) and non-migrant households (or non-migrants) with respect to activities that have important environmental 
consequences, such as resource use behavior and resource extraction technologies. ${ }^{1}$ Many recent studies have used this approach to assess the environmental effects of migration, most often in areas of destination (e.g., Browder 1995; Garland 1995; Pichon 1997; Sierra 1999; Perz 2003; Cassels et al. 2005). In contrast, there have been few studies examining the impacts of migration on the environment in areas of origin.

There is a large literature on the social and economic impacts of migration in rural areas of origin. Comparing migrant households and non-migrant households regarding agricultural production, use of agricultural technologies, and income and consumption is a common method of examining the influences of migration on rural people's life. Given the environmental consequences of these factors, this line of inquiry has direct implications for the subsequent environmental outcomes of migration in rural migrantsending areas. However, few previous studies have addressed such connections. Agricultural practices, incomes and assets, and consumption patterns are all critical elements of rural people's livelihood processes. Livelihood comprises the capabilities, assets (natural, physical, human, financial, and social), and activities required for a means of living (Carney 1998). The rural livelihoods framework provides a solid base to synthesize the literature on migration and rural livelihoods with the research on the environmental impacts of migration in rural origin areas. In the rural livelihoods framework, migration is considered one of the most important livelihood strategies, while the environment and natural resources are incorporated into the context, capital assets, strategies, and outcomes of livelihoods. The relationship between rural household-level population dynamics and the environment is a major area of recent population-environment research (de Sheerbinin et al. 2008). The household is also the primary scale of analysis in the rural livelihoods framework. Therefore, the household is an appropriate level of analysis for synthetic research on migration, rural livelihoods, and the environment. Rural household livelihoods can be conceptualized as an integrative mediating factor into the migration and environment model.

\footnotetext{
${ }^{1}$ In areas of origin, migrant households are those with member(s) outmigrating for various reasons, while those without migrant members are non-migrant households. In areas of destination, households which have newly moved into the community are migrant households, while those already locally established are non-migrant households. Rural migrant and non-migrant households in a specific study are exposed to the same social, economic, and biophysical environments. The method of comparing these two groups is largely equivalent to a pseudoexperimental design in which non-migrant households are employed as a control group so that the impacts of migration on migrant households can be assessed relative to those which do not participate in migration.
}

According to the conceptual framework depicted in Fig. 1, the impacts of rural out-migration on the rural environment are mediated by the intervening household livelihood factors including agricultural production, agricultural technology use, income and consumption, and resource use and management. ${ }^{2}$ It is hypothesized that rural migrant and non-migrant households differ significantly with respect to these four livelihood constructs. Such differences are expected to lead to distinct environmental outcomes in terms of changes in land quality, soil erosion, and forest re-growth. Here I empirically evaluate this conceptual framework in the context of rural-to-urban labor migration in Chongqing Municipality, Southwest China, a hilly-mountainous region currently with the highest rural labor out-migration rate in China. The study draws on data collected through rural household surveys and key informant interviews in four rural communities of Chongqing. The results confirm the research hypothesis that rural labormigrant and non-labor-migrant households are significantly different in livelihood activities. The implications of these findings for the subsequent environmental outcomes of rural labor out-migration and natural resource management in rural origin areas are also discussed.

\section{Literature Review}

One of the key areas of recent literature on the impacts of migration on rural livelihoods has focused on the differences between migrant and non-migrant households in agricultural production in rural origin areas. A popular view on the impacts of migration on agriculture is that rural labor outmigration leads to a decline in agricultural cultivation and production. Rural households with labor migrants were found to have lower agricultural productivity than those without migratory workers (Mazambani 1990; Rozelle et al. 1999; Schmook and Radel 2008). Nevertheless, an opposite view contends that remittances generated from labor migration increase rural household incomes and enable rural households to make agricultural improvements. Abundant empirical evidence from different regions has shown that the potential negative influences of lost household labor on agricultural production can be compensated by increased access to capital and enhanced agricultural investment (Taylor et al. 2003; de Haas 2006; McCarthy et al. 2006; Hull 2007). In addition, a "middle-path" finding from southcentral Ecuador showed that smallholder agriculture was not threatened by rural labor out-migration, nor were remittances invested in agricultural production and improvement (Jokisch 2002). This argument is supported by a recent

\footnotetext{
${ }^{2}$ For a detailed discussion of the full proposed conceptual model, see Qin (2009).
} 
Fig. 1 A conceptual framework for the impacts of rural migration on the rural environment, adapted from Qin (2009)

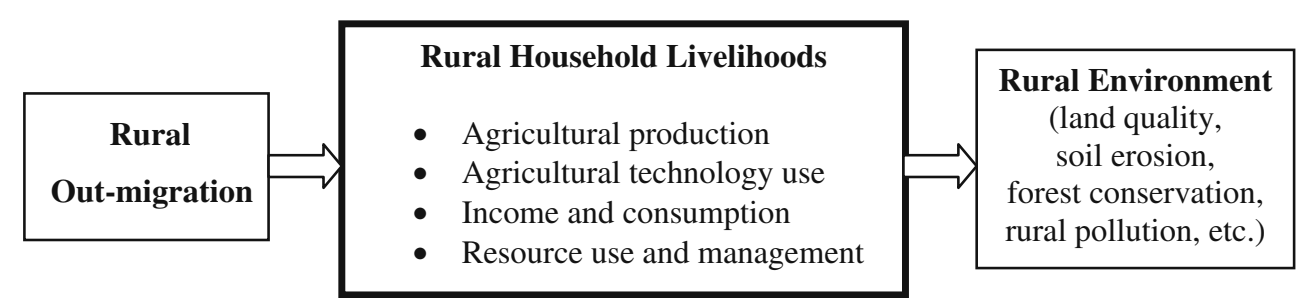

survey-based study in the southern Ecuadorian Andes, which suggests that migrant-sending households do not differ from non-migrant-sending households regarding the area cultivated in subsistence crops (Gray 2009). Taken together, these findings illustrate that rural labor migration has complicated and diverse effects on agricultural production practices.

A number of studies that have examined the influence of migration on rural household agricultural technology use also present opposing perspectives. The pessimistic view argues that labor scarcity resulting from rural out-migration leads to the decay and abandonment of traditional labor-intensive agricultural technologies by migrant households (Garcia-Barrios and Garcia-Barrios 1990; Zimmerer 1993), and prevents adoption of innovative agricultural technologies (Mazambani 1990; Black 1993). By contrast, Oberai and Bilsborrow (1984) argue that migration leads to technological improvement in rural areas through investment of remittances in more modern technologies and the stimulating effects of the new ideas and knowledge brought back by labor migrants. Other studies also found that labor-migrant households were more likely than non-labor-migrant households to use new farming technologies to improve agricultural productivity (Simelane 1995; Mendola 2008).

There is a general consensus that migration and remittances reduce rural poverty and contribute to the improvement of household living standards. Migrant households (especially those receiving remittances) normally have higher levels of income and consumption than nonmigrant households (Taylor and Mora 2006; Airola 2007; Schmook and Radel 2008; Wouterse and Taylor 2008). In terms of consumption patterns, several household surveybased studies showed that migrant households with remittances tended to spend more than non-migrant households on durable goods and productive activities (Zarate-Hoyos 2004; Adams 2006; Taylor and Mora 2006; Airola 2007). A subset of the research on the impacts of migration on household income and consumption has also assessed the differences between rural migrant and non-migrant households in asset accumulation (Adams 1998; Entwisle and Tong 2005; Ford et al. 2007; Garip 2007). Overall, these studies suggest the effects of rural out-migration on household assets differ across origin regions.

Finally, there is a common view that migrants differ significantly from non-migrants in terms of resource use behavior, resource extraction technologies, and knowledge of local ecosystems in rural areas of destination (Browder 1995; Garland 1995; Pichon 1997; Perz 2003). However, consistent support for such differences between migrants and nonmigrants in natural resource use is not always found in empirical research. And although it is often claimed that settlement of agricultural migrants in or near environmentally sensitive areas such as rainforest and wetlands leads to serious deforestation and environmental degradation (Bilsborrow 2002), some studies have shown that environmental degradation is not particularly associated with migrant households (Sierra 1999; Cassels et al. 2005). In addition, several studies relevant to the environmental consequences of migration in rural areas revealed that rural out-migration led to local labor shortage, which in turn disrupted traditional resource conservation practices (Collins 1988; Garcia-Barrios and Garcia-Barrios 1990; Zimmerer 1993). Thus, we may expect to find significant differences between migrant and non-migrant households regarding resource use and management in rural areas of origin.

In summary, research on migration and rural livelihoods compares the agricultural production, agricultural technology use, income and consumption, and asset accumulation of migrant and non-migrant households in migrant-sending areas, while research on the environmental impacts of rural migration focuses on the differences between migrants/ migrant households and non-migrants/non-migrant households in resource use and conservation in areas of destination. This study contributes to the existing literature by examining all these differences between migrant and non-migrant households in rural areas of origin.

\section{Methods}

\section{Study Area}

During the past 30 years, China has seen a large-scale flow of labor migrants from rural to urban areas. It is estimated that presently there are at least 140 million rural migrant workers in the cities of China, and this migrant population continues to grow (CMHRSS and CBS 2008). Chongqing Municipality in Southwest China currently has the highest percentage of rural work force as rural-to-urban labor migrants $(55.8 \%)$ among the provinces in China. Chongqing is a hilly-mountainous region characterized by eco- 
logical problems such as decreasing land fertility, soil erosion, and deforestation. The combination of ecological stress and high rates of rural-to-urban labor migration makes Chongqing an important study area for assessing the effects of rural migration on the rural environment.

The study communities were selected through a two-stage process. First, based on the official ecological zoning of Chongqing (Luo et al. 2006), five major ecological subregions were identified: the metropolitan core zone, the western hilly agricultural zone, the middle parallel-valley agricultural and forest zone, the Three Gorges Reservoir ecological zone, and the southeastern evergreen broadleaved forest zone. ${ }^{3}$ In addition, the 40 districts and counties under Chongqing's jurisdiction display significant variability in social and economic conditions. In Chongqing's 10th and 11th Five-Year Plans, the municipality is divided into three economic sub-regions according to geographic characteristics and socioeconomic development levels: the moredeveloped metropolitan area, the western economic corridor, and the Three Gorges Reservoir economic zone. By overlaying the five ecological zones with these three economic subareas, the study area was divided into four sub-regions in terms of social, economic, and ecological characteristics: the metropolitan eco-economic core area, the western-middle eco-economic corridor, the Three Gorges Reservoir eco-economic zone, and the southeastern ecoeconomic district (Fig. 2).

In the second stage, one village from each eco-economic sub-region was purposively selected according to two criteria: (1) high magnitude of rural-to-urban labor migration; and (2) abundance of natural resources such as farmland and forests. These two criteria magnify the connection between rural labor out-migration and the rural environment, and thus can facilitate understanding how rural-to-urban labor migration affects rural natural resource conservation. In sum, this two-stage selection procedure ensures heterogeneity among the final set of study communities, and helps capture the social, economic, and biophysical diversity across rural Chongqing. Four rural communities were thus selected for this study: Bailin Village (Beibei District) in the metropolitan eco-economic core area, Banliao Village (Wansheng District) in the western-middle eco-economic corridor, Dacao Village (Kaixian County) in the Three Gorges Reservoir ecoeconomic zone, and Tuanjie Village (Qianjiang District) in the southeastern eco-economic district (Fig. 2). Basic characteristics of these four study villages are summarized in Table 1, which shows community variations in labor

\footnotetext{
${ }^{3}$ Luo et al. (2006) described seven ecological sub-regions of Chongqing. For ease of classification, the soil-erosion sensitive Three Gorges Reservoir zone, the Three Gorges Reservoir man-made wetland zone, and the northeastern evergreen broad-leaved forest zone are merged into the Three Gorges Reservoir ecological zone.
}

migration rates, income levels, and natural resource endowments. Together these communities provide a representative sample of all rural areas in Chongqing.

\section{Data Collection}

The complexity of population-environment relationships necessitates the combination of multiple research methods. This study uses a mixed-methods approach to combine quantitative and qualitative methods (Tashakkori and Teddlie 1998). Analysis of secondary socioeconomic and biophysical data from statistic bureaus, environment protection agencies, and forestry administrations at different levels of government in Chongqing provided a structural context. Key informant interviews, conducted both before and along with rural household surveys, elicited detailed information about rural livelihood experiences for the survey questionnaire development, and provided a contextualized backdrop for the analysis of survey data. A total of 41 key informant interviews were conducted using a multiple-group and modified snowball sampling procedure (Luloff 1999). To represent the broad interests and perspectives in study communities, key informants were selected from a range of categories: village leaders, school administrators or teachers, senior residents, natural resource management staff, and agricultural extension workers. All in-depth interviews were taped, transcribed, and qualitatively analyzed to identify common themes (Dunn 2000). Key findings are included in the discussion section below to facilitate interpretation of survey results.

To empirically evaluate the efficacy of the rural migration-household livelihoods-rural environment conceptual model, a household survey was conducted to collect information about rural livelihood activities. The sample households were obtained using a stratified random sampling procedure (Singleton and Straits 2005). In each study community, a list of all households was compiled based on registration records. With the assistance of village leaders, these households were then subdivided into two groups according to their labor migration status. Households with at least one member working in an urban area for most of the time during the recent two years of survey were classified as labor-migrant households, while those with all members present for the period were classified as non-labor-migrant households. Finally, 45 households were randomly chosen from each category for survey sampling. Requests to participate in the survey were made in person, and all households contacted agreed to complete the survey. Whenever possible, households that could not be reached after repeated attempts were replaced by other randomly selected households from the same group. A total of 345 households (179 labor-migrant households and 166 nonlabor-migrant households) from the four study villages were surveyed using face-to-face questionnaire interviews. 


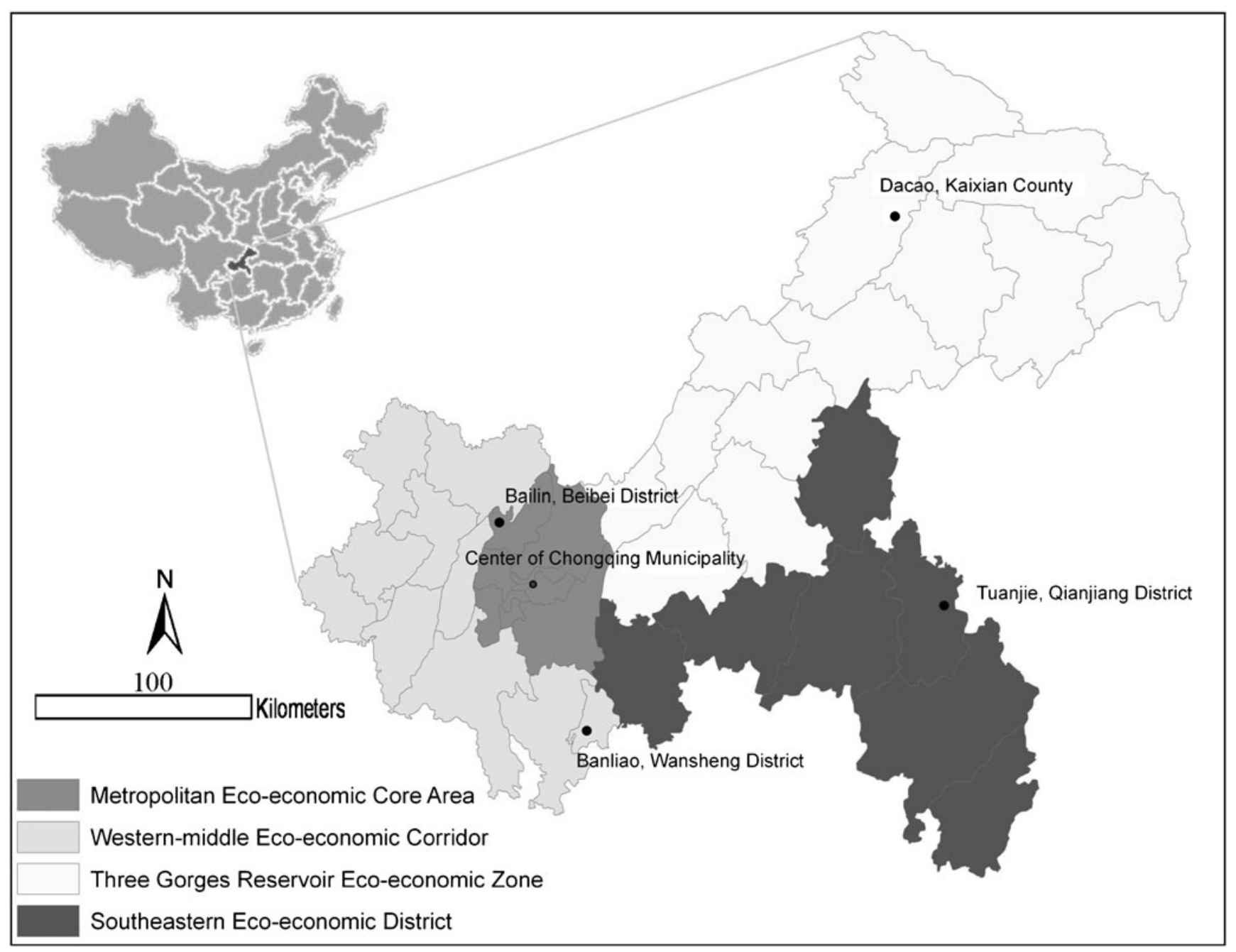

Fig. 2 Map of study communities in Chongqing Municipality, Southwest China

It is noteworthy that the non-labor-migrant households are not a homogenous group, and include households whose members are mainly engaged in agricultural production, as well as those which have at least one member working in local manufacturing enterprises or other nonfarm industries. Thus, the survey households can be further divided into three subgroups: 179 labor-migrant households, 76 local off-farm work households, and 90 farming

Table 1 General characteristics of study communities

\begin{tabular}{|c|c|c|c|c|c|c|}
\hline Study villages & $\begin{array}{l}\text { Number of } \\
\text { households }\end{array}$ & Population & $\begin{array}{l}\text { Number of labor } \\
\text { migrants }\end{array}$ & $\begin{array}{l}\text { Per capita annual income } \\
\text { (RMB) }\end{array}$ & $\begin{array}{l}\text { Farmland size } \\
(m u)\end{array}$ & $\begin{array}{l}\text { Forested land size } \\
(m u)\end{array}$ \\
\hline $\begin{array}{l}\text { Bailin } \\
\text { (Beibei) }\end{array}$ & 843 & 2,320 & 680 & 4,000 & 2,215 & 2,770 \\
\hline $\begin{array}{l}\text { Banliao } \\
\text { (Wansheng) }\end{array}$ & 819 & 3,080 & 900 & 2,500 & 2,482 & 7,590 \\
\hline $\begin{array}{l}\text { Dacao } \\
\quad \text { (Kaixian) }\end{array}$ & 728 & 3,016 & 800 & 3,200 & 1,298 & 2,258 \\
\hline $\begin{array}{l}\text { Tuanjie } \\
\text { (Qianjiang) }\end{array}$ & 647 & 2,328 & 500 & 2,200 & 1,982 & 5,900 \\
\hline
\end{tabular}

Notes: (1) $1 m u=0.165$ acres; (2) The exchange rate for US dollar to RMB was approximately 1:6.8 at the time of the survey (2008).

Source: Filed data collected from administration committees of study communities. 
households. ${ }^{4}$ All three subgroups are involved with agriculture to different extents.

\section{Measurement of Variables}

The survey addressed the four components of rural household livelihoods identified in the conceptual framework: (1) agricultural production; (2) use of agricultural technologies; (3) household income, expenditure, and assets; and (4) resource use and management. All of these were measured by multiple variables. In addition, a number of socio-demographic characteristics of households were included.

Four variables measured the agricultural production practices of rural households. Farmland use, the most important aspect of agricultural production, was measured by the size of per laborer cultivated land $(m u)$ in the year of the survey (2008). Respondents were also asked to indicate whether or not in 2008 their household was engaged in the following areas of agricultural production: (1) grain crops; (2) potatoes; (3) beans; (4) vegetables; (5) fruits; (6) oil plants; (7) commercialized poultry feeding; (8) aquaculture; and (9) livestock breeding. A measure of production diversity (total number of types of agricultural production involved) was created by summing up the dichotomous responses $(0=$ no, $1=$ yes $)$. Two other variables were included pertaining to the production of major grain crops in 2008: yield of rice $(\mathrm{kg})$ and yield of corn $(\mathrm{kg})$ per $m u$ of farmland.

Use of agricultural technologies was measured by three variables: the cost (in RMB) of chemical inputs, including fertilizers, pesticides, and herbicides, in the year prior to the survey (2007), and two constructed composite variables indicating the levels of use of different types of agricultural technologies. Respondents were asked to identify for the most recent year whether or not their household used 14 different agricultural techniques. The traditional farming technology category includes five: (1) tilling before cultivating crops; (2) applying organic fertilizer as base manure before planting; (3) intercropping; (4) multiple cropping; and (5) fixed crop rotation. The modern farming technology category includes nine practices: (1) using a large amount of chemical fertilizer; (2) applying chemical fertilizer according to the agricultural extension office's suggestions; (3) applying pesticide on farmland; (4) applying herbicide on farmland; (5) farming under plastic; (6) irrigating farmland with water pump; (7) using a machine for sowing; (8) using a machine for harvesting; (9) using no-tilling techniques. Responses $(0=$ no, $1=$ yes $)$ were summed up as two variables: total number of

\footnotetext{
${ }^{4}$ Households having both labor migrant and local off-farm work members were classified as labor-migrant households.
}

traditional agricultural techniques used and total number of modern agricultural techniques used.

Research has shown that household income and expenditure are especially difficult to measure in rural areas of developing countries. To reduce measurement error, the survey focused on the monetary components of rural household incomes and expenses. Household income was measured as annual cash income from both farming and non-farming sources in 2007. Household living expenditures referred to annual monetary spending on regular consumer goods and services in rural areas in 2007, excluding large, one off expenses (e.g., house construction) and the living costs of labor migrants or student members in urban areas. Per capita annual cash income and living expense (in RMB) were calculated to account for differences in a rural household's size and composition. In addition, an index variable was included as an indicator of household consumer assets, created according to Filmer and Pritchett (2001) using principle component analysis to derive weights for constructing a linear index of a group of asset variables. The asset indicators in this survey include household ownership of 19 different durable consumer goods, ${ }^{5}$ building materials and style of the household dwelling, and the household's drinking water sources. For ease of interpretation, the index was rescaled to a range from 0 to 5 .

Three variables were included pertaining to rural households' resource use and management activities. The proportion of firewood and crop residues in the total fuels used by a household indicated its dependency on biophysical resources for cooking and heating. Use of general forest resources was measured by asking respondents to identify whether or not their household regularly utilizes any types of timber and non-timber forest resources listed in the survey, including trees, mushrooms and fungi, medicinal materials and herbs, wild edible vegetables, wild fruits and nuts, nonprotected wild animals, and grazing for livestock. A new variable (total number of types of forest products or services used) was created based on the sum of responses $(0=$ no, $1=$ yes $)$ across these seven items. Respondents were also asked to indicate whether or not their household had undertaken any of the following natural resource improvement activities in the past twelve months: (1) planting trees or hedges on household farmland and/or forested land; (2) protecting trees in household farmland and/or forested land; (3) building stone or soil ridges on sloping farmland to prevent soil

\footnotetext{
${ }^{5}$ These durable consumer goods include bicycle, sewing machine, black/white television, color television, tape recorder, stereo, washing machine, electric fan, refrigerator, camera, VHS/DVD players, telephone, mobile phone, air conditioner, electric cooker, water heater, microwave oven, induction cooker, motorcycle, and automobile.
} 
erosion; (4) mending terrace ridges to prevent soil erosion; (5) maintaining and improving irrigation of farmland; (6) converting sloping farmland into terraces; (7) increasing the use of organic farm fertilizer; (8) reducing the use of artificial fertilizer and other chemicals; (9) planting legumes and other kinds of green manure crops; (10) practicing fallowing; (11) manually weeding household farmland and/or forested land; and (12) acquiring information on natural resources and the environment from sources such as television, newspapers, and magazines. Responses $(0=$ no, $1=$ yes) were summed up to create another composite variable of total number of resource improvement activities taken in the past year.

Furthermore, five socio-demographic variables were included in the analysis to account for the effects of basic household characteristics on livelihood activities. The use of these control variables allows for a more accurate evaluation of the differences between labormigrant households and non-labor-migrant households in rural livelihoods. The variables were: years of residence, household size, number of laborers in a household (including labor migrant members), mean age of laborers, and mean educational level of laborers. Educational attainment was measured by eight different levels in the survey: (1) little or no formal education; (2) less than an elementary school degree; (3) elementary school degree; (4) junior high school degree; (5) senior high school degree; (6) middle level professional, technical or vocational school degree; (7) two year associate degree; (8) four year college degree or above.

\section{Analytic Methods}

The statistical analysis of the rural household survey data included three phases. First, descriptive analyses of the data were used to describe survey sample characteristics and aggregate patterns of household livelihoods in the study area (results not included here). Next, variations between different household groups regarding livelihood variables and socio-demographic characteristics were explored with simple bivariate comparison statistics (independent $t$-test and one-way ANOVA). Finally, multivariate discriminant analysis was used to compare the differences between household groups in livelihood activities while controlling for the effects of household socio-demographic characteristics. This technique was particularly suitable here because it allowed for the comparison of two or more groups on multiple variables simultaneously. Discriminant analysis is usually used to classify known and unknown cases into categories. Here it is used to examine the multivariate differences between household groups, instead of maximizing the odds of correctly predicting the class of a particular case. The bivariate and multivariate analyses included both the comparison of labor-migrant and non-labor-migrant households and the comparison of labor-migrant, local offfarm work, and farming households.

\section{Results}

\section{Bivariate Comparisons}

As a preliminary step for the multivariate data analysis, bivariate statistical tests were conducted to identify socio-demographic and livelihood differences between household groups. Results of bivariate comparisons of labor-migrant and non-labor-migrant households are shown in Table 2, with significant variables highlighted. In sum, labor-migrant households differed significantly from non-labor-migrant households in all the five household socio-demographic characteristics. On average, labormigrant households lived longer in the village, and had more members and labor force than non-labor-migrant households. In general, laborers of labor-migrant households tended to be younger and more educated than those of non-labor-migrant households.

In addition, these two groups differed significantly in some of the livelihood variables. Notably, non-labormigrant households cultivated more land than labormigrant households on a per laborer basis. As expected, labor-migrant households on average enjoyed higher per capita cash income and more consumer assets than nonlabor-migrant households. Households with labor migrants also depended less on firewood and crop residues for fuel.

Table 2 also summarizes results of bivariate comparisons of labor-migrant, local off-farm work, and farming households. All the household socio-demographic variables again indicated significant differences among different household groups. Labor-migrant households and farming households in general lived longer in the village than local off-farm work households. On average, labor-migrant households were the largest in terms of household size and labor pool, followed by local off-farm work households, with farming households being the smallest. Active labor members of farming households also tended to be older and less educated than those of the other two groups.

Compared to the two-group comparisons, per capita annual cash consumption expenses differed significantly among household groups in the three-group comparisons. As shown in Table 2, farming households differed significantly regarding five livelihood indicators from the other two household groups. They cultivated more farmland on a per laborer basis, had lower per capita cash income and living expenditures and fewer consumer assets, and relied more on forests and crop residues for 
Table 2 Bivariate comparisons of household groups, given as means of variables

\begin{tabular}{|c|c|c|c|c|c|}
\hline \multirow[t]{2}{*}{ Variables } & \multicolumn{2}{|c|}{ Two household groups } & \multicolumn{3}{|c|}{ Three household groups } \\
\hline & $\begin{array}{l}\text { Non-labor-migrant } \\
(N=166)\end{array}$ & $\begin{array}{l}\text { Labor-migrant } \\
(N=179)\end{array}$ & $\begin{array}{l}\text { Farming } \\
(N=90)\end{array}$ & $\begin{array}{l}\text { Local off-farm work } \\
(N=76)\end{array}$ & $\begin{array}{l}\text { Labor-migrant } \\
(N=179)\end{array}$ \\
\hline \multicolumn{6}{|l|}{ Socio-demographic characteristics } \\
\hline Years of residence & $27.0^{* *}$ & $30.5 * *$ & $29.4^{* * *}$ & $24.2 * * *$ & $30.5^{* * *}$ \\
\hline Total number of household members & $3.9 * * *$ & $5.0^{* * *}$ & $3.5^{* * *}$ & $4.4 * * *$ & $5.0 * * *$ \\
\hline Number of household laborers & $2.5^{* * *}$ & $3.7 * * *$ & $2.2 * * *$ & $2.8 * * *$ & $3.7 * * *$ \\
\hline Average age of household laborers & $44.6^{* * *}$ & $40.4 * * *$ & $48.0^{* * *}$ & $40.5^{* * *}$ & $40.4 * * *$ \\
\hline $\begin{array}{l}\text { Average educational level of household } \\
\text { laborers }\end{array}$ & $2.9 * * *$ & $3.2 * * *$ & $2.6^{* * *}$ & $3.2 * * *$ & $3.2 * * *$ \\
\hline \multicolumn{6}{|l|}{ Agricultural production } \\
\hline Size of per laborer cultivated land $(m u)$ & $1.7 * * *$ & $1.1 * * *$ & $2.1 * * *$ & $1.2^{* * *}$ & $1.1 * * *$ \\
\hline $\begin{array}{l}\text { Total number of types of agricultural } \\
\text { production involved }\end{array}$ & 5.5 & 5.6 & 5.6 & 5.4 & 5.6 \\
\hline Yield of rice $(\mathrm{kg})$ per $m u$ of land & 433.7 & 396 & 447.9 & 416.9 & 396.0 \\
\hline Yield of corn $(\mathrm{kg})$ per $m u$ of land & 420.6 & 430.5 & 422.4 & 418.6 & 430.5 \\
\hline \multicolumn{6}{|l|}{ Use of agricultural technologies } \\
\hline $\begin{array}{l}\text { Expense of farming chemicals per } m u \text { of } \\
\text { land (RMB) }\end{array}$ & 268.3 & 262.6 & 282.9 & 251.0 & 262.6 \\
\hline $\begin{array}{l}\text { Total number of traditional agricultural } \\
\text { technologies used }\end{array}$ & 3.7 & 3.7 & 3.8 & 3.7 & 3.7 \\
\hline $\begin{array}{l}\text { Total number of modern agricultural } \\
\text { technologies used }\end{array}$ & 4.2 & 4.1 & 4.2 & 4.1 & 4.1 \\
\hline \multicolumn{6}{|l|}{ Household income, expenditure, and assets } \\
\hline Per capita annual cash income (RMB) & $2,534.7 * *$ & $3,675.5^{* *}$ & $1,560.9 * * *$ & $3,688.0^{* * *}$ & $3,675.5 * * *$ \\
\hline $\begin{array}{l}\text { Per capita annual cash living expenditure } \\
\text { (RMB) }\end{array}$ & $2,485.1$ & $2,711.6$ & $2,037.6^{* *}$ & $3,015.1 * *$ & $2,711.6^{* *}$ \\
\hline $\begin{array}{l}\text { Household consumer asset index } \\
\text { (rescaled to } 0-5 \text { ) }\end{array}$ & $2.1^{*}$ & $2.4^{*}$ & $1.8^{* * *}$ & $2.5^{* * *}$ & $2.4 * * *$ \\
\hline \multicolumn{6}{|l|}{ Resource use and management } \\
\hline $\begin{array}{l}\text { Proportion of firewood and crop residues in } \\
\text { total fuels }(\%)\end{array}$ & $54.6^{*}$ & $46.2^{*}$ & $62.0 * *$ & $45.9 * *$ & $46.2 * *$ \\
\hline $\begin{array}{l}\text { Total number of types of forest products } \\
\text { used }\end{array}$ & 0.7 & 0.6 & 0.8 & 0.6 & 0.6 \\
\hline $\begin{array}{l}\text { Total number of resource improvement } \\
\text { activities taken }\end{array}$ & 5.5 & 5.3 & 5.5 & 5.5 & 5.3 \\
\hline
\end{tabular}

Notes: (1)***sig. at the .001 level; **sig. at the .01 level; *sig. at the .05 level; (2) The independent $t$-test was used for the comparison of nonlabor-migrant and labor-migrant households; (3) One-way ANOVA was performed for the comparison of farming, local off-farm work, and labormigrant households

fuel. Overall, there was no significant difference between labor-migrant and local off-farm work households in these respects.

In summary, the bivariate analyses of survey results showed that in general rural labor-migrant households differed significantly from non-labor-migrant households in socio-demographic characteristics and measures for three of the four livelihood constructs in the conceptual model: agricultural production, income and consumption, and natural resource use. Moreover, the differences between these two groups were largely attributed to the differences between labor-migrant households and the farming household subgroup of non-labor-migrant households.
Multivariate Discriminant Analysis for Labor-Migrant and Non-labor-migrant Households

The bivariate comparisons above suggest that significant differences exist between labor-migrant and non-labormigrant households in rural livelihood activities. However, these simple analyses did not account for the effects of household socio-demographic characteristics and the interrelations among livelihood indicators. As noted earlier, multivariate discriminant analysis was conducted both for the comparison of labor-migrant and non-labor-migrant households and for the comparison of labor-migrant, local off-farm work, and farming households. In each phase of 
the analysis, blocks of variables were added to build multiple models to examine interactions among variables measuring different livelihood constructs, and to assess the extent to which different sets of livelihood variables distinguish household groups. A final reduced model was estimated by systematically removing non-significant variables from the full model until all the variables remaining in the model had significant effects.

The results of discriminant analysis of differences between labor-migrant and non-labor-migrant households in livelihood activities are presented in Table $3{ }^{6}$ The first model included only the four agricultural production variables. The size of per laborer cultivated land and the yield of rice per $m u$ of land had statistically significant effects in differentiating the two household groups (though only marginally significant for rice production). On average, households with labor migrants cultivated less farmland on a per laborer basis and had lower rice production for each $m u$ of farmland than those without migrant members. In Model 2, variables measuring agricultural technology use were introduced into the discriminant analysis. The size of per laborer cultivated land remained statistically significant in distinguishing between household groups, but the yield of rice per $m u$ of land was no longer significant. None of the three technological use indicators had significant effects in the model.

Model 3 added the three income and consumption variables. The size of per laborer cultivated land remained a powerful differentiator between labor-migrant and nonlabor-migrant households. The yield of rice per $m u$ of land became marginally significant again in the analysis. Variables measuring the use of technologies were still not statistically significant. Of the three newly introduced income and consumption indicators, only per capita annual cash income had a significant effect. Controlling for the effects of other variables in the model, labor-migrant households had higher levels of rural cash income than non-labor-migrant households on a per capita basis. The measures of natural resource use and management were introduced in Model 4, which included all the thirteen livelihood variables. None of the newly added indicators showed significant effects in the model. However, the three key differentiators in Model 3 (size of per laborer cultivated land, yield of rice per $m u$ of land, and per capita annual cash income) retained their statistical significance.

The full model (Model 5) added household sociodemographic characteristics to the discriminant analysis. All the five variables except household size showed

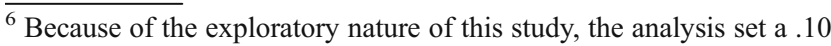
significance threshold instead of the more conventional .05 significance level.
}

significant differences between the two household groups. Labor-migrant households lived longer in the village and had more laborers than non-labor-migrant households. Their active labor members also tended to be younger and more educated. With the inclusion of socio-demographic characteristics, the size of per laborer cultivated land and the yield of rice per $m u$ of land were no longer statistically significant in distinguishing labor-migrant households from non-labor-migrant households. Per capita annual cash income remained statistically significant, but with weaker effect than in the previous models. Two other livelihood variables, the household consumer asset index and the proportion of firewood and crop residues in total fuels, became significant in the full model. Non-labor-migrant households on average owned fewer consumer assets and depended more on natural resources for fuel.

Finally, a reduced model was obtained by systematically eliminating non-significant variables from Model 5. The final model for multivariate comparison of labor-migrant and non-labor-migrant households included the yield of rice per $m u$ of land, per capita annual cash income, consumer asset index, proportion of firewood and crop residues in total fuels, and four household socio-demographic characteristics (length of residence, number of laborers, mean age of laborers, and mean educational level of laborers). Although the size of per laborer cultivated land attained statistical significance in the first four models, it was not significant in the full and the reduced models. This change suggests that the difference between labor-migrant and nonlabor-migrant households in per laborer cultivated farmland is explained away by their differences with respect to sociodemographic variables.

\section{Multivariate Discriminant Analysis for Labor-Migrant, Local Off-Farm Work, and Farming Households}

In order to enhance our understanding of the impacts of rural migration on household livelihoods, block discriminant models were also used to analyze differences among the three more narrowly-defined subgroups in the survey sample: labor-migrant households, local off-farm work households, and farming households (Table 4). When the model contained only the four agricultural production variables (Model 1), the size of per laborer cultivated land was statistically significant. Farming households in general cultivated more land than the other two groups on a per laborer basis. On average, each laborer of a local off-farm work household farmed approximately the same amount of land as that of a labor-migrant household. The other three variables were not significant.

Model 2 added the agricultural technology use measures to the multivariate analysis. The significance of the size of per laborer cultivated land remained unaffected. Expense of 
Table 3 Discriminant analysis of differences between labor-migrant and non-labor-migrant households, given as $\mathrm{F}$ values of variables

\begin{tabular}{|c|c|c|c|c|c|c|}
\hline Variables & Model 1 & Model 2 & Model 3 & Model 4 & Model 5 & Final model \\
\hline \multicolumn{7}{|l|}{ Agricultural production } \\
\hline Size of per laborer cultivated land $(m u)$ & $6.86^{* *}$ & $7.81 * *$ & $6.12 *$ & $5.25 *$ & 0.58 & \\
\hline Total number of types of agricultural production involved & 0.72 & 0.57 & 0.61 & 0.50 & 0.31 & \\
\hline Yield of rice $(\mathrm{kg})$ per $m u$ of land & $2.67^{(*)}$ & 2.31 & $2.72^{(*)}$ & $3.17^{(*)}$ & 1.85 & $2.69^{(*)}$ \\
\hline Yield of corn $(\mathrm{kg})$ per $m u$ of land & 0.02 & 0.10 & 0.10 & 0.09 & 0.02 & \\
\hline \multicolumn{7}{|l|}{ Use of agricultural technologies } \\
\hline Expense of farming chemicals per $m u$ of land (RMB) & & 1.34 & 0.69 & 0.54 & 0.88 & \\
\hline Total number of traditional agricultural technologies used & & 0.07 & 0.04 & 0.04 & 0.31 & \\
\hline Total number of modern agricultural technologies used & & 0.00 & 0.03 & 0.01 & 0.17 & \\
\hline \multicolumn{7}{|l|}{ Household income, expenditure, and assets } \\
\hline Per capita annual cash income (RMB) & & & $5.18^{*}$ & $5.56^{*}$ & $2.73^{(*)}$ & $3.70^{*}$ \\
\hline Per capita annual cash living expenditure (RMB) & & & 0.55 & 0.70 & 0.17 & \\
\hline Household consumer asset index & & & 1.65 & 0.98 & $4.19 *$ & $5.31^{*}$ \\
\hline \multicolumn{7}{|l|}{ Resource use and management } \\
\hline Proportion of firewood and crop residues in total fuels & & & & 0.73 & $3.47^{(*)}$ & $3.99 *$ \\
\hline Total number of types of forest products used & & & & 0.50 & 0.28 & \\
\hline Total number of resource improvement activities taken & & & & 0.76 & 0.08 & \\
\hline \multicolumn{7}{|l|}{ Socio-demographic characteristics } \\
\hline Years of residence & & & & & $5.85^{*}$ & $6.81 * *$ \\
\hline Total number of household members & & & & & 0.47 & \\
\hline Number of household laborers & & & & & $47.61 * * *$ & $64.70 * * *$ \\
\hline Average age of household laborers & & & & & $9.13 * *$ & $10.83^{* *}$ \\
\hline Average educational level of household laborers & & & & & $2.65^{(*)}$ & $3.01^{(*)}$ \\
\hline
\end{tabular}

$* * *$ sig. at the .001 level; **sig. at the .01 level; *sig. at the .05 level; $(*)$ marginally sig. at the .1 level

farming chemicals per $m u$ of land was also found to be statistically significant. Controlling for the effects of other variables in this model, farming households tended to spend the most money on fertilizers and plant pesticides per $m u$ of farmland, followed by labor-migrant households and local off-farm work households in turn.

In Model 3, the three rural income and consumption indicators were included as additional independent variables in the discriminant model. The size of per laborer cultivated land and the expense of chemicals per $m u$ of land remained statistically significant. Additionally, per capita annual cash income and the household consumer asset index were significant in differentiating household groups. Overall, farming households had substantially lower per capita rural income and fewer consumer assets than local off-farm work households and labor-migrant households, which had very close average values on these variables. Model 4 introduced measures of household natural resource use and management, none of which had a significant effect, but all the four significant variables in Model 3 retained their statistical significance. The yield of rice per $m u$ of land also showed marginal significance in this model. On average, farming households had the highest production of rice per unit of farmland, followed by local off-farm work households, and labor-migrant households the least.

Household socio-demographic characteristics were added to the analysis in Model 5. With their presence, per capita annual cash income and the yield of rice per $m u$ of land were no longer statistically significant among the three household groups. The other three previously significant variables remained significant, but the effects of the size of per laborer cultivated land and the household consumer asset index were weaker than in the previous models. In addition, the proportion of firewood and crop residues in total fuels became marginally significant in the full model. Local off-farm work and labor-migrant households had similar levels of dependence on forest and crop residues for fuel, which were substantially lower than that of farming households. All the socio-demographic measures except household size were also found to be statistically significant. In general, labor-migrant households lived slightly longer than farming households in the village, while both of these two groups had much longer residence than the local off-farm work household group. Labor-migrant households on average had the largest labor force, followed in turn by local off-farm work households and farming households. In 
Table 4 Discriminant analysis of differences among labor-migrant, local off-farm work, and farming households, given as F values of variables

\begin{tabular}{|c|c|c|c|c|c|c|}
\hline Variables & Model 1 & Model 2 & Model 3 & Model 4 & Model 5 & Final model \\
\hline \multicolumn{7}{|l|}{ Agricultural production } \\
\hline Size of per laborer cultivated land $(m u)$ & $10.78 * * *$ & $13.94 * * *$ & $10.77 * * *$ & $9.84 * * *$ & $3.76^{*}$ & \multirow[t]{2}{*}{$5.61 * *$} \\
\hline Total number of types of agricultural production involved & 0.47 & 0.50 & 0.76 & 0.82 & 0.85 & \\
\hline Yield of rice $(\mathrm{kg})$ per $m u$ of land & 1.63 & 1.41 & 1.91 & $2.20^{(*)}$ & 1.42 & \multirow[t]{2}{*}{$2.38^{(*)}$} \\
\hline Yield of corn $(\mathrm{kg})$ per $m u$ of land & 0.12 & 0.05 & 0.07 & 0.07 & 0.01 & \\
\hline \multicolumn{7}{|l|}{ Use of agricultural technologies } \\
\hline Expense of farming chemicals per $m u$ of land (RMB) & & $4.34 *$ & $3.24 *$ & $3.09 *$ & $4.48^{*}$ & \multirow[t]{3}{*}{$5.29 * *$} \\
\hline Total number of traditional agricultural technologies used & & 0.58 & 0.59 & 0.52 & 0.35 & \\
\hline Total number of modern agricultural technologies used & & 0.01 & 0.12 & 0.07 & 0.28 & \\
\hline \multicolumn{7}{|l|}{ Household income, expenditure, and assets } \\
\hline Per capita annual cash income (RMB) & & & $3.77 *$ & $3.97 *$ & 1.90 & \multirow[t]{2}{*}{$2.84 *$} \\
\hline Per capita annual cash living expenditure (RMB) & & & 0.64 & 0.64 & 0.26 & \\
\hline Household consumer asset index & & & $6.94 * *$ & $5.42 * *$ & $3.05 *$ & $3.87^{*}$ \\
\hline \multicolumn{7}{|l|}{ Resource use and management } \\
\hline Proportion of firewood and crop residues in total fuels & & & & 0.57 & $2.42^{(*)}$ & \multirow[t]{3}{*}{$3.11^{*}$} \\
\hline Total number of types of forest products used & & & & 0.26 & 0.26 & \\
\hline Total number of resource improvement activities taken & & & & 0.44 & 0.08 & \\
\hline \multicolumn{7}{|l|}{ Sociodemographic characteristics } \\
\hline Years of residence & & & & & $3.36^{*}$ & \multirow[t]{2}{*}{$3.27 *$} \\
\hline Total number of household members & & & & & 0.25 & \\
\hline Number of household laborers & & & & & $28.28 * * *$ & $38.70 * * *$ \\
\hline Average age of household laborers & & & & & $6.30 * *$ & $6.91 * *$ \\
\hline Average educational level of household laborers & & & & & $3.52 *$ & $3.95 *$ \\
\hline
\end{tabular}

$* * *$ sig. at the .001 level; **sig. at the .01 level; *sig. at the .05 level; $(*)$ marginally sig. at the .1 level

addition, farming households tended to have older and less educated laborers than the other two groups, which had almost the same aggregate results in this regard.

The final model included six livelihood variables and four household socio-demographic characteristics. Per capita annual cash income and the yield of rice per $m u$ of land showed significant effects again in the analysis. As compared with the final reduced model for the multivariate comparison of labor-migrant and non-labor-migrant households, two more livelihood variables (size of per laborer cultivated land and expense of farming chemicals per $m u$ of land) became significant in this model.

\section{Discussion}

This study empirically assesses the conceptual framework incorporating household livelihoods as a key mediating factor between rural migration and the rural environment. Results showed that with the exception of use of agricultural technologies, at least one variable measuring each livelihood construct in the conceptual model was statistically significant (albeit marginally significant in some cases) in differentiating rural labor-migrant households and non-labor-migrant households. In the discriminant analysis of differences among labor-migrant, local offfarm work, and farming households, all livelihood constructs had at least one measure with significant effect. These findings confirm the research hypothesis that labormigrant and non-labor-migrant household are significantly different with respect to livelihood activities.

Results also show that rural non-labor-migrant households are more heterogeneous than the literature often suggests. The comparison of labor-migrant, local off-farm work, and farming households found more significant differences among household groups than the comparison between labor-migrant and non-labor-migrant households in both the bivariate and the multivariate analyses. In sum, the analysis showed that livelihood differences between labor-migrant and non-labor-migrant households were largely due to the differences between labor-migrant and farming households, while labor-migrant households shared many similar livelihood characteristics with local off-farm work households.

The livelihood differences between rural labor-migrant and non-labor-migrant households have important implica- 
tions for the environmental outcomes of labor out-migration in rural origin areas. In developing countries rural poverty is often closely linked to environmental degradation, because the economically disadvantaged primarily live in rural areas and directly depend on local natural resources (Bilsborrow 1992). Rural population growth and persistent poverty can lead to the overexploitation and consequent deterioration of natural resources, which further threaten food security and rural livelihoods. This study shows one of the largest differences between these two household groups is in income and consumption, with labor-migrant households in general having higher rural cash income and consumer assets than non-labor-migrant households. Labor migration thus appears to contribute to increased capital assets and improved material well-being for participating households, and to reduce overall poverty in rural origin areas, which in turn can reduce pressure on local natural resources and promote sustainable rural development.

No significant difference was found between rural labormigrant and non-labor-migrant households with respect to cash living expenses. This is probably due to the fact that remaining members of rural migrant households are mostly elders and children, who generally have relatively lower levels of consumption. Another explanation for the seemingly limited impact of migration on rural consumption is that rural migrant households consider income from labor migration as temporary and hence do not increase consumption proportionally (Zhao 1999). Overall, rural labor out-migration has mixed impacts on rural consumption. On one hand, even if labor migrants do not remit enhanced income, their absence reduces overall rural household consumption needs. In addition, labor migration tends to check the increase in numbers of rural households because labor-migrant households are more likely than non-labormigrant households to maintain a multi-generational family structure, and thus may contribute to higher efficiency of rural household resource consumption. The combination of reduced absolute consumption demands and increased consumption efficiency can in turn lead to lower pressure on the rural environment. On the other hand, labor migration enhances the consumption level of rural migrant households. Key informant interviews revealed that migrant remittances generally improved the standard of living of rural households. One Banliao resident explained, "When people go to work in city and earn higher income, their families' food, clothing, and other living conditions will certainly get better. They have more money now, so they will consume more." In the bivariate comparisons involving the two subgroups of non-labor-migrant households, labormigrant households on average had significantly higher per capita annual cash living expenditure than farming households. Both the bivariate and multivariate discriminant analyses also showed that labor-migrant households had significantly more consumer assets than non-labor-migrant households (particularly farming households). Given the lack of efficient waste disposal in most rural areas of China, this increased household consumption may worsen already serious residential pollution problems in rural villages (Le 2004).

The results also showed that labor-migrant households used land less intensively (smaller cultivated land size per laborer, lower rice yield and fertilizer/pesticide expense per $m u$ of land) than non-labor-migrant households, particularly farming households. Additional analyses and comments of key informants revealed that labor migration served as a substitution for smallholder agricultural production, and that farming was generally left to the hands of older generations. Labor shortages resulting from the absence of key household laborers, combined with the unprofitability of agriculture, can lead to increasing abandonment of previously cultivated distant farmland. To the extent that most of the abandoned land is located on steep hillsides and of poor quality, less intensive cultivation should reduce pressure on local land resources. Many key informants commented on the natural re-growth of vegetation cover on recently abandoned farmland. As one Tuanjie Village informant described:

After those fields near the hill sides were left idle, grasses and trees grow up naturally there. Over time these fields largely become forested land. In a sense, abandoning farmland is just like reforesting the cultivated land. This should be good for reducing landslide and soil erosion.

Labor scarcity and land abandonment caused by rural labor out-migration have complex effects on land quality and soil erosion, especially in hill-mountain areas that have been substantially transformed by human settlement and maintained with labor-intensive production practices. Previous studies offer conflicting findings about the ecological impacts of labor migration and reduced agricultural intensity. It was found that migration-induced land abandonment contributed to less environmental degradation and more vegetation regeneration in the Swiss mountains, central Mexico, southern Bolivia, and many other Latin American countries (Preston et al. 1997; Preston 1998; Aide and Grau 2004; López et al. 2006; Gellrich et al. 2007), but accelerated rainfall runoff and soil erosion in the Ecuadorian Andes, Spanish Pyrenees, and Himalaya mountain regions (Harden 1993, 1996; Garcia-Ruiz et al. 1995). In addition, labor shortages caused by labor migration may have negative effects on agricultural biodiversity and sustainable agricultural practices (Zimmerer 1991; Hyden et al. 1993; Turner 1999). Impacts of labor-migrant households' withdrawal from agricultural production on rural land quality and soil erosion thus appear to largely depend 
on local ecological and socioeconomic characteristics. Although analysis of the in-depth interviews and the survey data suggested that rural labor migration led to a decline in cultivated farmland area and some land improvement in the study villages, systematic biophysical assessment is still needed for a more complete understanding of actual changes in land resource conditions.

Next, while uses of traditional and modern agricultural technologies were not statistically significant in distinguishing between rural labor-migrant and non-labor-migrant households, discriminant analysis showed that labormigrant households tended to spend less on agricultural chemicals than farming households. While this finding appears to contradict the New Economics of Labor Migration proposition that migration income is used to compensate for labor shortfalls and make agricultural improvement (Stark 1991; Taylor 1999), it is not surprising given the low returns of smallholder farming and the devaluation of agriculture in rural migrant households' diversified livelihood strategies. Since overfertilization and runoff are a major contributing factor to nonpoint source pollution in rural China, the reduction of chemical use by labor-migrant households may mitigate agricultural production pollution to some extent.

Finally, the results of both bivariate and multivariate analyses show that labor migration leads to reduced household dependence on forest resources for fuel, which should contribute to better land and forest conservation as firewood collection is a major cause of soil erosion and deforestation in rural areas of developing countries. ${ }^{7}$ Detailed comments of older informants about the changes in forest cover around the study communities suggest an emerging trend of forest recovery. As one resident from Dacao Village said:

When the farmland was contracted to individual households in 1981, these hills were almost bald. There was nothing on them. Now things are getting better. They are nearly all covered by trees. The mountain forests have been restored. The forests are so thick that people even can't go inside them.

Findings from the household survey and key informant interviews provide some support for the forest transition theory - a long-term sequence from initial deforestation due to human settlement to eventual forest recovery (Mather 1992). Rudel et al. (2005) identified two major pathways of forest recovery after agricultural expansion ends: (1) economic development and (2) forest scarcity. In the first,

\footnotetext{
${ }^{7}$ Key informant interviews also suggested that the difference in firewood use among labor-migrant, local off-farm work, and farming household groups would be even more salient due to the recent sharp increase in coal prices.
}

urbanization and economic development lead farmers to leave rural areas for better paying non-agricultural jobs. Labor loss increases farm worker wages in rural origin areas, which makes agricultural production even less profitable. Marginal farm lands are then abandoned and eventually return to forests. In the second case, increasing deforestation raises the prices of forest products, which in turn drives the trend of reforestation. States are usually critical actors in this type of forest recovery because they create forestation programs in response to forest scarcities. Rudel et al. (2005) assigned China to the "forest scarcity" category. However, this study shows that the case of rural Chongqing also fits well with the "economic development and labor migration" path. The proportion of forested land in Chongqing declined from $19 \%$ in the early 1950 s to less than $10 \%$ in the $1960 \mathrm{~s}$ and $1970 \mathrm{~s}$, but has maintained a constant increase since the 1980s and reached $34 \%$ in 2008 (Chongqing Bureau of Statistics 2009). Although the bulk of this substantial increase in Chongqing's forest cover is due to government-organized tree plantations and the Grain for Green Program, this analysis suggests an association between rural labor out-migration and ongoing forest recovery in the study area.

\section{Conclusions and Implications}

In this study, rural household livelihoods were conceptualized as an integrative mediating factor in a conceptual framework of rural migration and the rural environment. Findings based on the rural household survey data and key informant interviews confirm the research hypothesis that labormigrant and non-labor-migrant households are significantly different in rural livelihood activities. Results show that labormigrant households farm less intensively, have higher rural cash income, own more consumer assets, and depend less on biophysical resources for fuel than non-labor-migrant households. Moreover, rural non-labor-migrant households are an internally diverse rather than a homogenous group. Labormigrant households differed particularly from farming households in livelihood activities, while sharing many similar livelihood characteristics with local off-farm work households.

These findings have implications for rural environmental management and development policymaking and for future research. The general support found in the analysis for the conceptual model demonstrates its efficacy in improving our understanding of the environmental impacts of rural migration. The ultimate environmental consequences of labor out-migration in rural origin areas are contingent on the resulting changes in rural household livelihoods. The mediating livelihood variables between rural migration and the rural environment highlight potential areas for policy 
intervention. Rural migration can bring either dramatic gains or losses to the long-term conservation of local natural resources. Thus, future rural environmental management policies should aim at providing favorable institutional conditions to facilitate the potentially positive environmental outcomes of labor migration while avoiding or minimizing the possible negative ones.

The relationships among rural migration processes, household livelihoods, and rural environmental changes are influenced by the broader social and economic contexts at national and regional levels. Under the Household Responsibility System in rural China, farmers own farmland in the name of the local village community and do not have individual land property rights. Thus, a migrant household cannot sell its farmland even if all of its active labor members move to urban areas for nonagricultural jobs. At the same time, labor-migrant households are unwilling to give up their land because it is seen as a safety net against insecure urban employment. As a consequence of household labor shortages, labor-migrant households often under-cultivate or even abandon their farmland. The relationship between agricultural land use and the rural environment is especially complicated in hilly-mountainous areas of developing countries. While rural-to-urban labor migration and abandonment of farmland may facilitate forest transition and ecological recovery, abandoned lands may fail to rehabilitate naturally because they have been irreversibly transformed. Integrated resource management plans should be implemented promptly to optimize the ecological effects of rural labor migration and concomitant household agricultural adjustment. Policies encouraging ecosystem recovery on abandoned land (e.g., planting trees or other perennials) can promote sustainable land use and reduce water and soil erosion. Meanwhile, it is of great importance to develop holistic policies and programs to enhance both rural people's socioeconomic welfare and rural environmental sustainability. A better incorporation of policies on rural labor migration with development and environmental conservation programs in China (e.g., poverty reduction policies and the Grain for Green Program) can further improve ecological restoration in rural areas. ${ }^{8}$

This analysis shows that local off-farm work households are quite similar to labor-migrant households in terms of

\footnotetext{
${ }^{8}$ The dual urban-rural structure and the rigid household registration system are commonly recognized as major underlying determinants of the large-scale circular rural-to-urban labor migration flows. In June 2007, Chongqing was designated the largest experimental area for the coordinated and balanced urban-rural development reform in China. Although the social and economic ramifications of this reform are still unfolding, a better integration of urban and rural areas and progressive adjustments in the household registration system may bode a gradual shift from temporary or circular labor migration to permanent settlement in cities for rural migrants. Any resulting changes in the rural migration patterns will also result in new trends for the migration impacts to the rural environment in the long term.
}

livelihood activities, and are even better off in some respects, such as living expenses and consumer assets. Since local non-agricultural employment does not result in the prolonged absence of key household laborers, this strategy should achieve a better combination of resourcebased and non-resource-based activities in rural household livelihood portfolios. Therefore, creating more nonagricultural employment opportunities within commuting distance from rural communities without causing environmental degradation can enhance the sustainability of agricultural production and natural resource use.

The environmental impacts of rural migration in rural origin areas are seldom systematically assessed. This research suggests that rural out-migration leads to lower dependency on agriculture and local natural resources for subsistence, and that a trend toward vegetation regeneration is emerging in the study area. However, these relationships are too tenuous to predict an extensive ecological recovery across rural Chongqing. This study underscores the need to systematically monitor and investigate changes in land quality, soil erosion, and forest cover over time in rural areas experiencing high magnitude of labor out-migration. Better longitudinal biophysical data at both the macro and the micro levels are needed to improve research and management of rural natural resources following rural out-migration.

Finally, this study has methodological implications for future research on rural migration, livelihoods, and the environment. The findings show that a simplistic dichotomous typology of migrant and non-migrant households neglects complexity within the two populations. In fact, non-migrant households are a diverse group, and migrant households can also be further classified based on characteristics of labor migrants, such as gender, household member status (e.g., household head or offspring), length of participation in labor migration, and migration destination (e.g., within or outside province/region, domestic or international). Accounting for variations within both migrant and non-migrant household groups in further studies is important to advance our understanding of the impacts of rural migration on household livelihoods and consequent environmental changes.

Acknowledgements This research was supported by a Doctoral Dissertation Research Improvement grant from the Geography and Spatial Sciences Program of the National Science Foundation, and dissertation research funds from the Worldwide Universities Network, the Rural Sociological Society, and the University of Illinois. An earlier version of this article was presented at the Association of American Geographers Annual Meeting in Las Vegas, Nevada, March 2009. I am very grateful to my advisor Courtney Flint and dissertation committee members (Jeffrey Dawson, Futing Liao, and Stephen Gasteyer) for their insightful guidance throughout this project. Special thanks go to the community leaders and residents who supported and participated in this research. Thoughtful comments from the three anonymous reviewers and the journal editor are also sincerely appreciated. 


\section{References}

Adams, R. (1998). Remittances, investment, and rural asset accumulation in Pakistan. Economic Development and Cultural Change 47(1): $155-173$.

Adams, R. (2006). Remittances, poverty and investment in Guatemala. In Özden, Ç., and Schiff, M. (eds.), International Migration, Remittances, and the Brain Drain. World Bank, Washington, DC, pp. 53-80.

Aide, T. M., and Grau, H. R. (2004). Globalization, migration, and Latin American ecosystems. Science 305: 1915-1916.

Airola, J. (2007). The use of remittance income in Mexico. International Migration Review 41(4): 850-859.

Bilsborrow, R. E. (1992). Rural poverty, migration and the environment in developing countries: three case studies. World Bank Policy Research Working Paper (WPS 1017).

Bilsborrow, R. E. (2002). Migration, population change, and the rural environment. Environmental Change and Security Project Report 8: 69-94.

Black, R. (1993). Migration, return, and agricultural development in the Serra Do Alvao, Northern Portugal. Economic Development and Cultural Change 41(3): 563-585.

Browder, J. (1995). Redemptive communities: indigenous knowledge, colonist farming systems, and conservation of tropical forest. Agriculture and Human Values 12(1): 17-30.

Carney, D. (ed.) (1998). Sustainable Rural Livelihoods: What Contribution Can We Make? Department for International Development (DFID). UK, London.

Carr, D. (2009). Population and deforestation: why rural migration matters? Progress in Human Geography 33(3): 355-378.

Cassels, S., Curran, S. R., and Kramer, R. (2005). Do migrants degrade coastal environments? Migration, natural resource extraction and poverty in North Sulawesi, Indonesia. Human Ecology 33(3): 329-363.

China Ministry of Human Resources and Social Security (CMHRSS) and China Bureau of Statistics (CBS) (2008). China Human Resources and Social Security Development Report 2008. Available online at: http://www.stats.gov.cn/tjgb/qttjgb/qgqttjgb/ t20090519_402559984.htm (in Chinese).

Chongqing Bureau of Statistics (2009). Analysis on the environmental conditions of Chongqing in the 60 years since the establishment of New China. Available online at: http://www.cqtj.gov.cn/ UploadFile/20090922111903281.pdf (in Chinese).

Collins, J. (1988). Unseasonal Migrations: The Effects of Rural Labor Scarcity in Peru. Princeton University Press, Princeton, NJ.

de Haas, H. (2006). Migration, remittances and regional development in Southern Morocco. Geoforum 37(4): 565-580.

de Sheerbinin, A. D., VanWey, L., McSweeney, K., Aggarwal, R., Barbieri, A., Henry, S., Hunter, L. M., and Twine, W. (2008). Rural household demographics, livelihoods and the environment. Global Environmental Change 18(1): 38-53.

Dunn, K. (2000). Interviewing. In Hay, I. (ed.), Qualitative Research Methods in Human Geography. Oxford University Press, New York, pp. $50-82$.

Entwisle, B. and Tong, Y. (2005). The impact of migration and remittances on households in rural Thailand. Paper presented at the annual meeting of the Population Association of America, Philadelphia, March 31-April 2.

Filmer, D., and Pritchett, H. (2001). Estimating wealth effects without expenditure data - or tears: an application to educational enrollments in states of India. Demography 38(1): 115-132.

Ford, K., Jampaklay, A., and Chamratrithirong, A. (2007). The impact of migration on household wealth in Kanchanaburi Province, Thailand. Paper presented at the annual meeting of the Population Association of America, New York, March 29-31.
Garcia-Barrios, R., and Garcia-Barrios, L. (1990). Environmental and technological degradation in peasant agriculture: a consequence of development in Mexico. World Development 18(11): 1569 1585 .

Garcia-Ruiz, J. M., Lasanta, T., Ortigosa, L., Ruiz-Flafio, P., Marti, C., and Gonzalez, C. (1995). Sediment yield under different land uses in the Spanish Pyrenees. Mountain Research and Development 15(3): 229-240.

Garip, F. (2007). Internal migration, remittances and community development. Paper presented at the annual meeting of the Population Association of America, New York, March 29-31.

Garland, E. B. (1995). The social and economic causes of deforestation in the Peruvian Amazon Basin: natives and colonists. In Painter, M., and Durham, W. H. (eds.), The Social Causes of Environmental Destruction in Latin America. The University of Michigan Press, Ann Arbor, pp. 217-246.

Gellrich, M., Baur, P., Koch, B., and Zimmermann, N. (2007). Agricultural land abandonment and natural forest re-growth in the Swiss mountains: a spatially explicit economic analysis. Agriculture, Ecosystems and Environment 118(1-4): 93-108.

Gray, C. L. (2009). Rural out-migration and smallholder agriculture in the Southern Ecuadorian Andes. Population and Environment 30 (4-5): 193-217.

Harden, C. P. (1993). Land use, soil erosion, and reservoir sedimentation in an Andean drainage basin in Ecuador. Mountain Research and Development 13(2): 177-184.

Harden, C. P. (1996). Interrelationships between land abandonment and land degradation: a case from the Ecuadorian Andes. Mountain Research and Development 16(3): 274-280.

Hull, J. (2007). Migration, remittances, and monetization of farm labor in subsistence sending areas. Asian and Pacific Migration Journal 16(4): 451-484.

Hyden, G., Turner II, B. L., and Kates, R. (1993). Beyond intensification. In Turner II, B. L., Hyden, G., and Kates, R. (eds.), Population Growth and Agricultural Change in Africa. University of Florida Press, Gainesville, pp. 320-360.

Jokisch, B. D. (2002). Migration and agricultural change: the case of smallholder agriculture in highland Ecuador. Human Ecology 30 (4): $523-550$.

Jolly, C. L. (1994). Four theories of population change and the environment. Population and Environment 16(1): 61-90.

Le, X. (2004). The impacts of rural living styles on the rural environment in China. Agricultural Environment and Development 21(4): 42-45 (in Chinese).

López, E., Boccoa, G., Mendoza, M., Velázquez, A., and Aguirre-Rivera, J. (2006). Peasant emigration and land-use change at the watershed level: a GIS-based approach in central Mexico. Agricultural Systems 90(1-3): 62-78.

Luloff, A. E. (1999). The doing of rural community development research. Rural Society 9(1):313-327.

Luo, H., Zhu, B., Liu, D., and He, X. (2006). Regionalization of ecological function in Chongqing Municipality, China. Acta Ecologica Sinica 26(9): 3144-3151 (in Chinese).

Mackellar, F. L., Lutz, W., McMichael, A. J., and Suhrke, A. (1998). Population and climate change. In Rayner, S., and Malone, E. L. (eds.), Human Choice and Climate Change, vol. 1. Battelle Press, Columbus, pp. 89-193.

Marquette, C. M., and Bilsborrow, R. (1999). Population and environment relationships in developing countries: recent approaches and methods. In Sundberg, B., and Moomaw, W. R. (eds.), People and Their Planet. St. Martin's Press, New York, pp. $29-44$.

Mather, A. (1992). The forest transition. Area 24(4): 367-379.

Mazambani, D. (1990). Labor Migration Impacts on Communal Land Agriculture: Case Studies from Manicaland Province, Zimbabwe, Doctoral Dissertation, Clark University, Worcester, Massachusetts. 
McCarthy, N., Carletto, G., Davis, B., and Maltsoglou, I. (2006). Assessing the impact of massive out-migration on agriculture. Agricultural and Development Economics Division of the Food and Agriculture Organization of the United Nations, Working Paper No. 06-14.

Mendola, M. (2008). Migration and technological change in rural households: complements or substitutes? Journal of Development Economics 85(1): 150-175.

Oberai, A. S., and Bilsborrow, E. (1984). Theoretical perspectives on migration. In Bilsborrow, R. E., Oberai, A. S., and Standing, G. (eds.), Migration Surveys in Low-income Countries: Guidelines for Survey and Questionnaire Design. Croom Helm, London and Sydney, pp. 14-30.

Perz, S. G. (2003). Social determinants and land use correlates of agricultural technology adoption in a forest frontier: a case study in the Brazilian Amazon. Human Ecology 31(1): 133-165.

Pichon, F. J. (1997). Settler households and land-use patterns in the Amazon frontier: farm-level evidence from Ecuador. World Development 25(1): 67-91.

Preston, D. (1998). Post-peasant capitalist graziers: The 21st century in southern Bolivia. Mountain Research and Development 18(2): 151-158.

Preston, D., Macklin, M., and Warburton, J. (1997). Fewer people, less erosion: the twentieth century in southern Bolivia. The Geographical Journal 163(2): 198-205.

Qin, H. (2009) The Impacts of Rural-to-Urban Labor Migration on the Rural Environment in Chongqing Municipality, Southwest China: Mediating Roles of Rural Household Livelihoods and Community Development, Doctoral Dissertation, University of Illinois at Urbana-Champaign, Urbana, Illinois.

Rozelle, S., Taylor, J. E., and de Brauw, A. (1999). Migration, remittances, and agricultural productivity in China. The American Economic Review 89(2): 287-291.

Rudel, T., Coomes, O., Moran, E., Achard, F., Angelsen, A., Xu, J., and Lambin, E. (2005). Forest transitions: towards a global understanding of land use change. Global Environmental Change 15(1): 23-31.

Schmook, B., and Radel, C. (2008). International labor migration from a tropical development frontier: globalizing households and an incipient forest transition. Human Ecology 36(6): 891-908.
Sierra, R. (1999). Traditional resource-use systems and tropical deforestation in a multiethnic region in northwest Ecuador. Environmental Conservation 26(2): 136-145.

Simelane, H. S. (1995). Labour migration and rural transformation in post-colonial Swaziland. Journal of Contemporary African Studies 13(2): 207-226.

Singleton Jr., R. A., and Straits, B. C. (2005). Approaches to Social Research (4th edition). Oxford University Press, New York.

Stark, O. (1991). The Migration of Labor. Basil Blackwell, Cambridge, Massachusetts.

Tashakkori, A., and Teddlie, C. (1998). Mixed Methodology: Combining Qualitative and Quantitative Approaches. Sage Publications, Thousand Oaks, California.

Taylor, J. (1999). The new economics of labour migration and the role of remittances in the migration process. International Migration 37(1): $63-88$.

Taylor, J. and Mora, J. (2006). Does migration shape expenditures in rural households? World Bank Policy Research Working Paper 3842.

Taylor, J., Rozelle, S., and de Brauw, A. (2003). Migration and incomes in source communities: a new economics of migration perspective from China. Economic Development and Cultural Change 52(1): 75-101.

Turner, M. D. (1999). Labor process and the environment: the effects of labor availability and compensation on the quality of herding in the Sahel. Human Ecology 27(2): 267-296.

Wouterse, F., and Taylor, J. (2008). Migration and income diversification: evidence from Burkina Faso. World Development 36(4): 625-640.

Zarate-Hoyos, G. A. (2004). Consumption and remittances in migrant households: toward a productive use of remittances. Contemporary Economic Policy 22(4): 555-565.

Zhao, Y. (1999). Leaving the countryside: rural-to-urban migration decision in China. The American Economic Review 89(2): 281-286.

Zimmerer, K. S. (1991). Labor shortages and crop diversity in the southern Peruvian Sierra. Geographical Review 81(4): 414-432.

Zimmerer, K. S. (1993). Soil erosion and labor shortages in the Andes with special reference to Bolivia, 1953-91: implications for “conservation-with-development". World Development 21(10): $1659-1675$. 